\title{
Generation of hydrogen peroxide from San Joaquin Valley particles in a cell-free solution
}

\author{
H. Shen ${ }^{1}$, A. I. Barakat ${ }^{2}$, and C. Anastasio ${ }^{1}$ \\ ${ }^{1}$ Department of Land, Air and Water Resources, University of California, Davis, One Shields Avenue, Davis, CA 95616, USA \\ ${ }^{2}$ Department of Mechanical and Aeronautical Engineering, University of California, Davis, One Shields Avenue, Davis, \\ CA 95616, USA
}

Received: 24 July 2010 - Published in Atmos. Chem. Phys. Discuss.: 7 September 2010

Revised: 21 December 2010 - Accepted: 23 December 2010 - Published: 26 January 2011

\begin{abstract}
Epidemiological studies have shown a correlation between exposure to ambient particulate matter (PM) and adverse health effects. One proposed mechanism of PMmediated health effects is the generation of reactive oxygen species (ROS) - e.g., superoxide $\left({ }^{\bullet} \mathrm{O}_{2}^{-}\right)$, hydrogen peroxide $(\mathrm{HOOH})$, and hydroxyl radical $\left({ }^{\bullet} \mathrm{OH}\right)$ - followed by oxidative stress. There are very few quantitative, specific measures of individual ROS generated from PM, but this information would help to more quantitatively address the link between ROS and the health effects of PM. To address this gap, we quantified the generation of $\mathrm{HOOH}$ by $\mathrm{PM}$ collected at an urban (Fresno) and rural (Westside) site in the San Joaquin Valley (SJV) of California during summer and winter from 2006 to 2009. HOOH was quantified by HPLC after extracting the PM in a cell-free, phosphate-buffered saline (PBS) solution with or without $50 \mu \mathrm{M}$ ascorbate (Asc). Our results show that the urban PM generally generates much more $\mathrm{HOOH}$ than the rural PM but that there is no apparent seasonal difference in $\mathrm{HOOH}$ generation. In nearly all of the samples the addition of a physiologically relevant concentration of Asc greatly enhances $\mathrm{HOOH}$ formation, but a few of the coarse PM samples were able to generate a considerable amount of $\mathrm{HOOH}$ in the absence of added Asc, indicating the presence of unknown reductants. Normalized by air volume, the fine $\mathrm{PM}\left(\mathrm{PM}_{2.5}\right)$ generally makes more $\mathrm{HOOH}$ than the corresponding coarse PM ( $\mathrm{PM}_{\mathrm{cf}}$, i.e., 2.5 to $\left.10 \mu \mathrm{m}\right)$, primarily because the mass concentration of $\mathrm{PM}_{2.5}$ is much higher than that of $\mathrm{PM}_{\mathrm{cf}}$. However, normalized by PM mass, the coarse PM typically generates more $\mathrm{HOOH}$ than the fine PM. The amount of HOOH produced by SJV PM is reduced
\end{abstract}

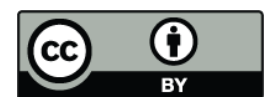

Correspondence to: C. Anastasio (canastasio@ucdavis.edu) on average by $(78 \pm 15) \%$ when the transition metal chelator desferoxamine (DSF) is added to the extraction solution, indicating that transition metals play a dominant role in $\mathrm{HOOH}$ generation. By measuring calibration curves of $\mathrm{HOOH}$ generation from copper, and quantifying copper concentrations in our particle extracts, we find that PBS-soluble copper is primarily responsible for $\mathrm{HOOH}$ production by the Fresno PM. Extrapolating our results to expected concentrations of $\mathrm{PM}$-derived $\mathrm{HOOH}$ in human lung lining fluid suggests that typical daily PM exposures in the San Joaquin Valley are unlikely to cause $\mathrm{HOOH}$-mediated acute health effects, but that very high PM events might lead to cytotoxic levels of pulmonary $\mathrm{HOOH}$.

\section{Introduction}

Ambient particulate matter (PM) can have adverse health effects at relatively low concentrations (Shy, 1979; Ware et al., 1981), with epidemiological studies showing robust correlations between PM exposure and adverse health effects such as human pulmonary and cardiovascular morbidity and mortality (Pope et al., 1995, 2004; Dockery et al., 1993; Pekkanen et al., 2002; Pope and Dockery, 2006). While the pathways involved in this relationship remain to be clarified, one proposed mechanism is PM-mediated generation of reactive oxygen species (ROS), which then causes oxidative stress and cell damage ( $\mathrm{Li}$ et al., 2008; Valavanidis et al., 2008; Gonzalez-Flecha, 2004; Donaldson et al., 2003). The major ROS species include superoxide $\left({ }^{\bullet} \mathrm{O}_{2}^{-}\right)$, hydrogen peroxide $(\mathrm{HOOH})$, and hydroxyl radical $\left({ }^{\bullet} \mathrm{OH}\right)$. These species can be formed by transition metals (M) in the presence of reductant (e.g., ascorbate) via reactions such as

Published by Copernicus Publications on behalf of the European Geosciences Union. 
$\mathrm{M}($ red $)+\mathrm{O}_{2} \rightarrow \mathrm{M}($ ox $)+{ }^{\bullet} \mathrm{O}_{2}^{-}$

$\mathrm{M}(\mathrm{red})+{ }^{\bullet} \mathrm{O}_{2}^{-}+2 \mathrm{H}^{+} \rightarrow \mathrm{M}(\mathrm{ox})+\mathrm{HOOH}$

$\mathrm{M}($ red $)+\mathrm{HOOH} \rightarrow \mathrm{M}(\mathrm{ox})+{ }^{\bullet} \mathrm{OH}+\mathrm{OH}^{-}$

$\mathrm{M}(\mathrm{ox})+\mathrm{Asc}(\mathrm{red}) \rightarrow \mathrm{M}($ red $)+\mathrm{Asc}(\mathrm{ox})$

where (red) and (ox) represent reduced and oxidized forms, respectively, of the metals and ascorbate.

In vivo, $\mathrm{HOOH}$ is produced in cells as a product of oxygen metabolism and at physiological concentrations $\mathrm{HOOH}$ plays a role in cell signaling (Forman et al., 2010). High local concentrations of $\mathrm{HOOH}$ are involved in inflammatory disease states and in host defense against bacterial pathogens in higher animals (Hyslop et al., 1988, 1995; Oosting et al., 1990). Through the respiratory burst, inflammatory cells can produce 20 to $120 \mu \mathrm{M}$ of $\mathrm{HOOH}$, levels that can impair intracellular calcium and energy homeostasis, activate the glutathione redox cycle, induce lipid peroxidation and DNA strand breaks, cause cell death, and either inhibit or destroy bacteria (Hyslop et al., 1988, 1995; Oosting et al., 1990; Laskin et al., 2003). A number of in vitro studies have shown that cytotoxicity and cell injury can be induced at the lowest $\mathrm{HOOH}$ concentrations tested, typically 50 to $100 \mu \mathrm{M}$ (Oosting et al., 1990; Holm et al., 1991; Geiser et al., 2004; Crim and Longmore, 1995; Sporn et al., 1992; LaCagnin et al., 1990; Hyslop et al., 1988); the threshold for acute $\mathrm{HOOH}$-mediated injury might actually be at lower concentrations, but such levels were not examined. In contrast, an in vivo study has shown that inhalation exposure of rats to 10 to $100 \mathrm{ppbv}$ of gas-phase $\mathrm{HOOH}$ only modestly, and sometimes inconsistently, augments the negative effects of inhaled fine ammonium sulfate particles (Morio et al., 2001). Overall, $\mathrm{HOOH}$ is generally regarded as being less toxic than ${ }^{\bullet} \mathrm{OH}$, which can cause a variety of oxidative damage to cell DNA as well as membrane lipids and proteins (Valavanidis et al., 2008). However, HOOH likely has significant indirect biological effects since this small uncharged molecule diffuses across membranes easily, is relatively long lived (LaCagnin et al., 1990), and is a precursor of highly toxic ${ }^{\bullet} \mathrm{OH}$ (Feierman et al., 1985).

While inhaled highly soluble gases such as $\mathrm{HOOH}$ will be removed by the wet membranes of the upper airways, particles - including those that generate $\mathrm{HOOH}$ and other ROS can be deposited deep into the lung (Wexler and Sarangapani, 1998; Sarangapani and Wexler, 2000). Given the potential link between ROS generation and PM toxicity, a number of studies have measured the oxidative potential of particles extracted in cell-free buffer solutions (Prahalad et al., 2001; Shi et al., 2003; Baulig et al., 2004; Kunzli et al., 2006; Hasson and Paulson, 2003; Arellanes et al., 2006; Cho et al., 2005; Venkatachari et al., 2005, 2007; Vidrio et al., 2009; Alaghmand and Blough, 2007; Jung et al., 2006; Hung and Wang, 2001; Hewitt and Kok, 1991; DiStefano et al., 2009; Wang et al., 2010). Many of these studies have used methods that are not specific to individual ROS, but others have specifically measured ${ }^{\circ} \mathrm{OH}$ (Alaghmand and Blough, 2007; Kunzli et al., 2006; Vidrio et al., 2009; Shi et al., 2003; Jung et al., 2006; DiStefano et al., 2009) or HOOH (Hasson and Paulson, 2003; Arellanes et al., 2006; Hewitt and Kok, 1991; Wang et al., 2010). Studies by Paulson and coworkers have shown that $\mathrm{HOOH}$ is generated from aqueous extracts of both fine and coarse particles collected in the Los Angeles air basin and that dissolved transition metals, including $\mathrm{Fe}, \mathrm{Cu}$ and $\mathrm{Zn}$, are correlated with $\mathrm{HOOH}$ generation from the coarse particles (Hasson and Paulson, 2003; Arellanes et al., 2006; Wang et al., 2010).

Redox-active transition metals such as iron $(\mathrm{Fe})$ and copper $(\mathrm{Cu})$, are common components of PM that play an important role in ROS generation by particles (Zepp et al., 1992; Donaldson et al., 1997; Deguillaume et al., 2005; Wang et al., 2010). Transition metal-mediated overproduction of ROS can lead to oxidative stress, inflammation, mutagenesis, cell proliferation, and eventually cardiopulmonary diseases and cancer (Kennedy et al., 1998; Jimenez et al., 2000; Prahalad et al., 1999; Hetland et al., 2000; Ghio et al., 1999; Knaapen et al., 2002; Schaumann et al., 2004; Donaldson et al., 2003). Previous studies have shown that $\mathrm{Fe}$ and $\mathrm{Cu}$ are most efficient in PM-mediated ROS generation (Donaldson et al., 1997; Vidrio et al., 2008, 2009; Shi et al., 2003; DiStefano et al., 2009; Wang et al., 2010). Furthermore, several studies have shown that the addition of a metal chelator, desferoxamine mesylate (DSF), can inhibit ${ }^{\bullet} \mathrm{OH}$ production from particles and prevent ${ }^{\bullet} \mathrm{OH}$-mediated injury (Donaldson et al., 1997; Prahalad et al., 2001; Alaghmand and Blough, 2007; Vidrio et al., 2009).

Although most studies of PM oxidative potential have not quantitatively measured individual reactive oxygen species, such information would be useful to more quantitatively examine the link between ROS and the health effects of PM. In addition, quantifying the generation of specific oxidants - such as $\mathrm{HOOH} \mathrm{-} \mathrm{by} \mathrm{PM} \mathrm{in} \mathrm{cell-free} \mathrm{assays} \mathrm{is} \mathrm{a} \mathrm{relatively}$ rapid screening tool that can help select the most active particle samples for further toxicity evaluation by in vitro and in vivo assays. To address this gap, we have measured the generation of $\mathrm{HOOH}$ by fine $\left(\mathrm{PM}_{2.5}\right)$ and coarse $\left(\mathrm{PM}_{2.5}\right.$ to 10$)$ particles collected at an urban (Fresno) and rural (Westside) site in the San Joaquin Valley (SJV) of California during summer and winter. The main objectives of the current study are: (1) to quantify the amounts of $\mathrm{HOOH}$ generated from SJV PM; (2) to compare $\mathrm{HOOH}$ generation from an urban and rural site during different seasons and within different size ranges; (3) to examine the importance of added reductant (ascorbate) on $\mathrm{HOOH}$ formation; and (4) to evaluate the contribution of transition metals in general - and $\mathrm{Cu}$ in particular - to $\mathrm{HOOH}$ production. 


\section{Materials and methods}

\subsection{Chemicals}

Ascorbic acid (Asc, $\geq 99.0 \%$ ), chelex-100 sodium form resin, copper (II) sulfate $\left(\mathrm{CuSO}_{4} 5 \mathrm{H}_{2} \mathrm{O}, 98+\%\right.$, A.C.S. reagent grade), desferoxamine mesylate (DSF, 95\% TLC), $\mathrm{Na}_{2} \mathrm{H}_{2}$ EDTA (molecular biology grade), and horseradish peroxidase type II (HRP) were purchased from Sigma. 4hydroxyphenylacetic acid (POPHAA) was from TCI America. Nitric acid $\left(\mathrm{HNO}_{3}\right.$, Optima), potassium hydrogen phthalate (KHP, A.C.S.), potassium phosphate monobasic $\left(\mathrm{KH}_{2} \mathrm{PO}_{4}, \mathrm{HPLC}\right.$ grade), sodium chloride ( $\mathrm{NaCl}$, A.C.S.), sodium hydroxide $(\mathrm{NaOH}$, A.C.S.), sodium phosphate dibasic $\left(\mathrm{Na}_{2} \mathrm{HPO}_{4}\right.$, A.C.S. $)$, and sulfuric acid $\left(\mathrm{H}_{2} \mathrm{SO}_{4}\right.$, Optima $)$ were from Fisher Scientific. All chemicals were used as received. Purified water $(\geq 18.2 \mathrm{M} \Omega \mathrm{cm})$ was obtained using a Milli-Q Plus system (Millipore).

\subsection{Surrogate lung fluid (SLF)}

Experiments were performed in a cell-free SLF solution that contained $114 \mathrm{mM} \mathrm{NaCl}$ and $10.0 \mathrm{mM}$ total phosphate (7.8 $\mathrm{mM} \mathrm{Na}_{2} \mathrm{HPO}_{4}$ and $2.2 \mathrm{mM} \mathrm{KH}_{2} \mathrm{PO}_{4}$ ) to buffer the solution at $\mathrm{pH} 7.2$ to 7.4. Transition metals were removed from the SLF by running the solution slowly through a chelex-100 sodium form resin column. The SLF was kept at 4 to $8{ }^{\circ} \mathrm{C}$ and used within a month of preparation. Immediately prior to sample extraction, in most samples $50 \mu \mathrm{M}$ of freshly made Asc was added to the SLF to mimic endogenous levels of this reductant (Yokoyama et al., 2000; van der Vliet et al., 1999; Cross et al., 1994). Although Asc is not the only reductant in human lung lining fluid, for simplicity it is the only antioxidant we included in this work.

\subsection{PM collection and extraction}

PM samples were collected at an urban (Fresno) and rural (Westside) site in California's SJV during summer and winter between 2006 and 2009 by other researchers from UC Davis. The Fresno sampling site was at 550 East Shaw Avenue, located in a mixed residential and retail commercial setting approximately 2 blocks east of Highway 41 . The Westside sampling site is surrounded by agricultural fields, located approximately 35 miles southwest of Fresno and 10 miles east of Interstate 5 on the west side of the SJV. PM samples were collected at a flow rate of $1.465 \mathrm{~m}^{3} / \mathrm{min}$ using a high volume sampler (Thermo-Anderson GS2310-105) with an inlet (Mode G1231) for $\mathrm{PM}_{\mathrm{cf}}$ and a single stage impactor (Mode SA 231) for $\mathrm{PM}_{2.5}$. For each sample, particles were collected for $6 \mathrm{~h}$ (10:00 a.m. to 04:00 p.m.) per day over the course of ten days (two five-day sampling periods separated by a two-day interval with no sampling); this schedule was established for concurrent animal exposure experiments (Wilson et al., 2010). $\mathrm{PM}_{2.5}$ samples were collected on 8 in $\times 10$ in filters made of either pure Teflon (PALL Inc.) (most samples) or of TX40 (Teflon-coated borosilicate glass microfibers) (for the 2007 Westside and 2009 Fresno samples). Aluminum foil was baked at $400{ }^{\circ} \mathrm{C}$ for $24 \mathrm{~h}$ and then put into the sampler to collect $\mathrm{PM}_{\mathrm{cf}}$. The dates of PM collection and the collected PM mass concentration of each sample are shown in Table 1.

A custom-made punch with a stainless steel blade was used to cut fine PM filter pieces of a uniform size. Based on 10 replicate punches, the average \pm 1 SD surface area of each cut piece was $18.4 \pm 0.8 \mathrm{~mm}^{2}$. A ceramic blade (Fine Science Tools Inc.) was used to cut coarse PM foil pieces of a uniform size. Based on 10 replicate cuts, the average \pm 1 SD length of each cut foil piece was $5.4 \pm 0.5 \mathrm{~mm}$; the width of each piece was the manufactured width of each foil strip $(10 \mathrm{~mm})$.

For $\mathrm{HOOH}$ measurements, a punch of filter (for fine PM samples) or a piece of foil (for coarse PM samples) was placed in a 7-mL PFA (perfluoroalkoxy Teflon) vial containing $4.0 \mathrm{~mL}$ of SLF with, generally, $50 \mu \mathrm{M}$ Asc. Prior to use, the PFA vials were thoroughly washed (including a 1-h soak in $2 \mathrm{M} \mathrm{HNO}_{3}$ followed by copious Milli-Q rinsing), air-dried, and completely wrapped with aluminum foil to keep dark. After adding the SLF and PM, vials were shaken in the dark at room temperature for up to $4 \mathrm{~h}$ in a wrist-action shake table (VWR OS-500) set at "5". For every experiment day we also "extracted" three different types of controls: (1) a positive control consisting of $250 \mathrm{nM}$ of $\mathrm{CuSO}_{4}$, (2) an SLF solution blank, and (3) corresponding field blanks, i.e., filter or foil substrate that had been put into the sampler in the field without drawing any air through the substrate. These controls were treated the same way as PM samples.

A microbalance (CAHN C-33; sensitivity of $0.1 \mu \mathrm{g}$ ) was used to get the mass of each PM filter or foil piece before and after PM extraction, as well as to determine the mass of extracted foil pieces that were wiped clean using a cotton swab soaked in $70 \%$ ethanol. For each extraction, the extracted PM mass was determined by the difference of the mass of filter or foil piece before and after PM extraction. We also measured the total collected coarse PM mass by the difference of the masses of foil pieces before PM extraction and after foil extraction and cleaning.

In order to examine the role of transition metals in $\mathrm{HOOH}$ formation, in some experiments DSF was added to the SLF to get a final concentration of $1.0 \mathrm{mM}$ prior to adding PM. DSF removes the ability of transition metals to form ROS (Vidrio et al., 2009; Donaldson et al., 1997); therefore, comparison of $\mathrm{HOOH}$ levels in the absence and presence of DSF reveals the role that transition metals play in $\mathrm{HOOH}$ production from PM.

\subsection{HOOH measurements using HPLC}

$\mathrm{HOOH}$ was analyzed using the post-column derivatization, fluorescence HPLC method of Kok et al. (1995). In this method, $\mathrm{HOOH}$ is first separated from other sample 
Table 1. Sample dates of collection, total and extracted mass concentrations, and SLF-soluble Cu mass concentrations.

\begin{tabular}{|c|c|c|c|c|c|c|c|}
\hline \multirow[t]{2}{*}{$\begin{array}{l}\text { Sample } \\
\text { ID }^{\mathrm{a}}\end{array}$} & \multirow[t]{2}{*}{$\begin{array}{l}\text { Dates of } \\
\text { Collection }\end{array}$} & \multicolumn{2}{|c|}{$\begin{array}{l}\text { Collected Mass Conc. } \\
\qquad\left(\mu \mathrm{g} \mathrm{m}^{-3}\right)\end{array}$} & \multicolumn{2}{|c|}{$\begin{array}{l}\text { Extracted Mass Conc. } \\
\qquad\left(\mu \mathrm{g} \mathrm{m}^{-3}\right)\end{array}$} & \multicolumn{2}{|c|}{$\begin{array}{l}\text { Soluble Cu Mass Conc. } \\
\left(\mathrm{ng} \mathrm{m}^{-3}\right)\end{array}$} \\
\hline & & Fine $^{b}$ & Coarse $^{c}$ & Fine & Coarse & Fine & Coarse \\
\hline \multicolumn{8}{|c|}{ Fresno Samples } \\
\hline FRSU06 & 5-9 \& 12-16 Sep 2006 & 30.0 & $14.0 \pm 2.8$ & $20.9 \pm 5.9$ & $12.7 \pm 2.4$ & $13.7 \pm 5.9$ & $3.0 \pm 0.8$ \\
\hline FRWI07 & 13-17 \& 20-24 Feb 2007 & 15.5 & $2.1 \pm 0.3$ & $11.4 \pm 1.4$ & $0.8 \pm 0.4$ & $40.5 \pm 10.6$ & $3.8 \pm 2.5$ \\
\hline FRSU08 & $24-28 \& 31$ Aug-4 Sep 2008 & 49.3 & $4.0 \pm 0.8$ & $41.5 \pm 6.7$ & $3.2 \pm 0.7$ & $25.2 \pm 10.1$ & $2.8 \pm 1.7$ \\
\hline FRWI09 & 10-14 \& 17-21 Jan 2009 & 38.1 & $3.6 \pm 1.5$ & $28.1 \pm 4.0$ & $2.7 \pm 0.6$ & $8.6 \pm 3.2$ & $3.4 \pm 0.4$ \\
\hline \multicolumn{8}{|c|}{ Westside Samples } \\
\hline WESU07 & $14-18 \& 21-25$ Aug 2007 & 26.1 & $3.0 \pm 0.2$ & $18.0 \pm 7.6$ & $2.8 \pm 0.2$ & $1.0 \pm 0.6$ & $0.6 \pm 0.6$ \\
\hline WEWI08 & $6-10 \& 13-17$ Feb 2008 & 22.8 & $5.0 \pm 0.4$ & $17.7 \pm 8.0$ & $3.7 \pm 0.3$ & $2.1 \pm 0.7$ & $0.6 \pm 0.5$ \\
\hline
\end{tabular}

${ }^{\text {a }}$ Sample nomenclature: FR = Fresno, WE = Westside, $\mathrm{SU}=$ summer, WI = winter, \#\# = year $(20 \mathrm{xx}),{ }^{\mathrm{b}}$ collected mass concentration provided by the San Joaquin Valley Aerosol Health Effects Research Center (SAHERC) on the UCD campus, ${ }^{\mathrm{c}}$ collected mass concentration calculated from our measurements. Values are means $( \pm$ SD), calculated for $n=$ 5 to 8 for collected and extracted mass concentrations and $n=4$ to 6 for SLF-soluble $\mathrm{Cu}$ mass concentrations (determined from sample extract solutions containing ascorbate but no DSF). The ratios of soluble Cu mass over collected PM mass are 0.46, 2.61, 0.51, 0.22, 0.04, and 0.09 ng $\mu^{-1}$ for the fine PM from FRSU06, FRWI07, FRSU08, FRWI09,

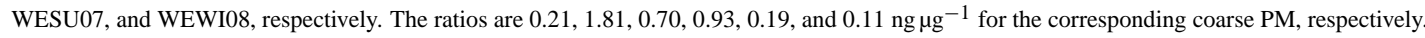

components by the HPLC column and then reacted with HRP, which subsequently oxidizes POPHAA to form the highly fluorescent POPHAA dimer, which is quantified by the HPLC detector. Our HPLC consisted of a Shimadzu LC-10AT pump, an Inertsil ${ }^{\circledR}$ ODS-2 analytical column $(4.6 \times 250 \mathrm{~mm}, 5 \mu \mathrm{m}$ bead) with an attached guard column, and a Shimadzu RF-551 spectrofluorometric detector (detector sensitivity: low; response time: $1.5 \mathrm{~s}$; range: $\times 1$; wavelengths of excitation and emission of 320 and $400 \mathrm{~nm}$, respectively). The eluent was $1.0 \mathrm{mM} \mathrm{H}_{2} \mathrm{SO}_{4}$ and $0.10 \mathrm{mM}$ $\mathrm{Na}_{2} \mathrm{H}_{2}$ EDTA in Milli-Q water, continuously degassed with a slow stream of helium $(99.997 \%)$, and run at a flow rate of $0.60 \mathrm{~mL} / \mathrm{min}$. The fluorescence reagent $(250 \mathrm{mM} \mathrm{KHP \text {, }}$ $238 \mathrm{mg} / \mathrm{L} \mathrm{HRP}$, and $11 \mathrm{mM}$ POPHAA, with $\mathrm{pH}$ adjusted with $\mathrm{NaOH}$ to 5.8 to 6.0 ) was filtered after being made. During use, it was placed on ice to slow the thermal dimerization of POHPAA and was delivered at a rate of $0.06 \mathrm{~mL} / \mathrm{min}$ by a peristaltic pump. A $500 \mu \mathrm{L}$ aliquot of PM extraction solution was analyzed for $\mathrm{HOOH}$ after $0,1,2$, and $4 \mathrm{~h}$ of shaking. The extract was filtered using a $0.22 \mu \mathrm{m}$ syringe filter (Milex ${ }^{\circledR}$ Millipore) and then immediately injected into the HPLC using an all-glass syringe.

\subsection{ICP-MS analysis of transition metals}

$400 \mu \mathrm{L}$ of the 4-h PM extract was filtered (as in Sect. 2.4), diluted with $3.6 \mathrm{~mL}$ of $3 \% \mathrm{HNO}_{3}$ into a $15-\mathrm{mL}$ Corning ${ }^{\circledR}$ polypropylene centrifuge tube, and stored in the refrigerator for analysis of $\mathrm{Cu}, \mathrm{Fe}, \mathrm{V}$, and $\mathrm{Mn}$. A series of standards containing these and other metals for ICP-MS analysis was prepared in SLF using CLÅRITAS PPT ${ }^{\circledR}$ Memory Test 1 metal standards (SPEX Certiprep ${ }^{\circledR}$ ). The standards were diluted the same way as the samples.

\subsection{Data analysis}

Two quantities were determined for each particle extract: (1) the initial rate of $\mathrm{HOOH}$ formation, calculated using the $0 \mathrm{~h}$ and $1 \mathrm{~h}$ time points, and (2) the maximum $\mathrm{HOOH}$ formed during the $4 \mathrm{~h}$ of extraction. Our rate of $\mathrm{HOOH}$ formation is likely an underestimate of the true value since our first time point is at $1 \mathrm{~h}$ and not earlier. Similarly, for the few samples that show $\mathrm{HOOH}$ concentrations increasing throughout the $4 \mathrm{~h}$ of extraction, the maximum $\mathrm{HOOH}$ we report will be less than the true maximum.

The rate of $\mathrm{HOOH}$ formation in a given PM sample was blank- and positive-control-corrected and normalized for sampled air volume using:

Corrected Rate of $\mathrm{HOOH}\left(\mathrm{nmol} \mathrm{h}^{-1} \mathrm{~m}^{-3}\right)$

$=\frac{\text { Sample Rate }- \text { Field Blank Rate }}{\text { Daily Positive Control Rate }- \text { Daily SLF Blank Rate }}$

$\times \frac{\text { Average Positive Control Rate } \times 1000 \mathrm{nmol}_{\mu \mathrm{mol}^{-1}} \times \text { ExtractVolume }}{\text { Air }}$ Air Volume Sampled

All rates here are in $\mu \mathrm{M} \mathrm{h}^{-1}$. The extract volume is $0.004 \mathrm{~L}$, while the air volume sampled represents the volume corresponding to the $\mathrm{PM}_{2.5}$ filter punch $\left(2.346 \mathrm{~m}^{3}\right.$-air) or $\mathrm{PM}_{\mathrm{cf}}$ foil piece $\left(21.444 \mathrm{~m}^{3}\right.$-air). The average positive control rate for our experiments with $50 \mu \mathrm{M}$ Asc and no DSF was $26.7 \pm 0.9 \mu \mathrm{M} \mathrm{h}^{-1}$. Field blank values under these conditions were low: on average, they were only $10 \%$ higher than the SLF blank rate and only $5 \%$ of the average Fresno sample rate. Analogous equations were used to determine the airvolume-normalized maximum amount of $\mathrm{HOOH}$ formation 
(Average Positive Control Maximum $=35.7 \pm 3.8 \mu \mathrm{M}$ ) and to determine PM-mass-normalized rates and maxima. We normalized sample results to the positive control because we found that $\mathrm{HOOH}$ generation from the positive control was covariant with sample and blank values on a given day, with positive control (and sample replicate) values varying within a range of approximately $-30 \%$ to $+20 \%$.

Data were expressed as means $\pm \mathrm{SD}$ and analyzed using SPSS 12.0 (SPSS Inc.) and SigmaPlot 8.0 (Systat Software Inc.). Comparisons of $\mathrm{HOOH}$ generation among different PM samples were performed using one-way ANOVA with post hoc comparisons of the means using the Bonferroni method. A statistical value of $P<0.05$ was considered significant.

\section{Results and discussion}

The total and extracted mass concentrations of the SJV PM samples are shown in Table 1 and Fig. S1. The collected fine PM mass was 2 to 9 times higher than the corresponding coarse PM mass, and there were no apparent site or seasonal differences in total PM mass (Fig. S1, Table 1). Our PM extraction in SLF was generally quite efficient, removing 69 to $84 \%$ (average of $(75 \pm 6) \%$ ) and 75 to $97 \%$ (average of $(78 \pm 22) \%)$ of the collected fine and coarse PM mass, respectively; the one exception was $37 \%$ removal for the coarse PM sample from Fresno in winter 2007 (Fig. S2).

Figure 1 shows some examples of the time course of $\mathrm{HOOH}$ generation from SJV PM and the $\mathrm{Cu}$ (II) positive control during our 4-h extraction. We stopped the extraction at $4 \mathrm{~h}$ because initial measurements showed that $\mathrm{HOOH}$ generation from the Fresno fine $\mathrm{PM}$ and $\mathrm{Cu}$ (II) positive control decreased after this time (data not shown). Solution and field blanks all generated very low background levels of $\mathrm{HOOH}$, as shown in Fig. 1. In contrast, $\mathrm{HOOH}$ produced from the positive control reached a concentration of approximately $30 \mu \mathrm{M}$ at $1 \mathrm{~h}$ and was typically slightly higher at later times. As illustrated in Fig. 1, the Fresno PM was much more active in forming $\mathrm{HOOH}$ than was the Westside PM. As described in Sect. 2.6, we used the 0 and $1 \mathrm{~h}$ time points to estimate the initial rate of $\mathrm{HOOH}$ formation and used the highest concentration of $\mathrm{HOOH}$ measured during the $4 \mathrm{~h}$ as an estimate of the maximum level.

We have normalized our $\mathrm{HOOH}$ formation rate and maximum concentration in each PM extract in two different ways: (1) to the volume of air sampled during particle collection (e.g., nmol-HOOH h${ }^{-1} \mathrm{~m}^{-3}$-air) and (2) to the extracted PM mass (e.g., nmol-HOOH h $\mathrm{h}^{-1} \mathrm{mg}^{-1}$-PM). The air-volumenormalized $\mathrm{HOOH}$ generation is relevant to ambient PM inhalation studies, where PM exposure is determined by the PM mass concentration and inhaled air volume. On the other hand, the PM-mass-normalized $\mathrm{HOOH}$ generation is relevant to PM instillation studies, which use a given mass of PM. In addition, the air-volume-normalized result is useful for

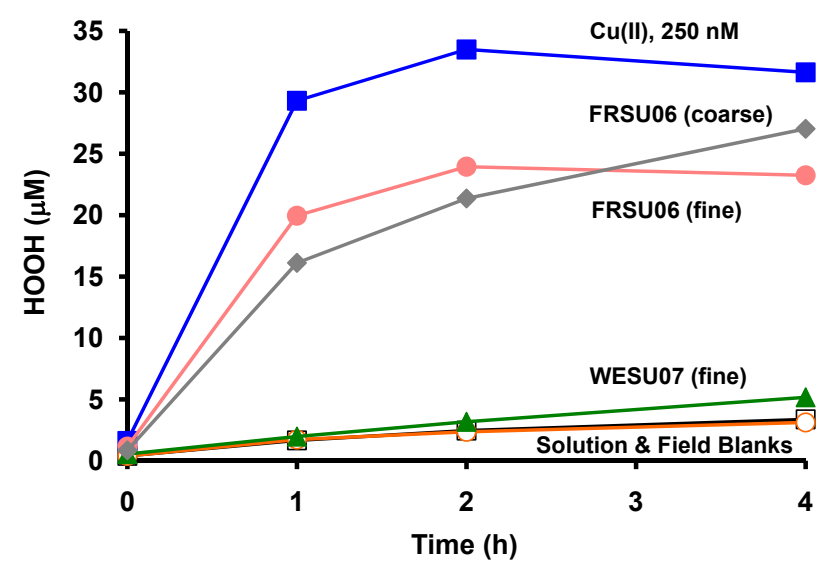

Fig. 1. Examples of $\mathrm{HOOH}$ generation from fine and coarse San Joaquin Valley particle samples extracted in a surrogate lung fluid containing ascorbate: FRSU06 $=$ Fresno summer 2006, WESU07 = Westside summer 2007. $250 \mathrm{nM} \mathrm{Cu}$ (II) was used as the positive control. The solution and field blanks generated very similar, low background $\mathrm{HOOH}$ levels.

understanding PM-mediated $\mathrm{HOOH}$ exposures for a given period at a given site (since it integrates both the reactivity of the PM and its concentration), while the PM-massnormalized result gives information about the PM reactivity.

\subsection{Generation of $\mathrm{HOOH}$ in PM extracts with added ascorbate}

We first quantified $\mathrm{HOOH}$ generation from SJV PM extracted in SLF with added Asc. Ascorbate, which can act as either an antioxidant or a pro-oxidant depending upon the circumstances (Padayatty et al., 2003; McGregor and Biesalski, 2006; Satoh and Sakagami, 1997; Stadtman, 1991), is found in lung lining fluid, plasma, other extracellular fluids and in intracellular compartments in almost all organisms (Cross et al., 1994; McGregor and Biesalski, 2006). In the presence of transition metals, ascorbate can recycle oxidized forms of metals to their reduced forms, which can lead to the generation of more ROS (Vidrio et al., 2008; Satoh and Sakagami, 1997). The concentration of Asc that we used, $50 \mu \mathrm{M}$, is at the lower end of concentrations measured in human lung lining fluid (Cross et al., 1994; van der Vliet et al., 1999).

In general, the Fresno (urban) particles were much more reactive than the Westside (rural) particles in generating $\mathrm{HOOH}$, both for air-volume and PM-mass normalizations. This is shown for initial rates of $\mathrm{HOOH}$ formation in Fig. 2a and b: on average, the Fresno fine and coarse particles are 21 and 18 times more reactive, respectively, than their Westside counterparts for air-volume normalized rates and 22 and 43 times higher, respectively, for PM-mass normalized rates. On an air-volume-normalized basis, the fine particles were generally much more reactive in producing $\mathrm{HOOH}$ than were the coarse particles (Fig. 2a), while the reverse was true for the 


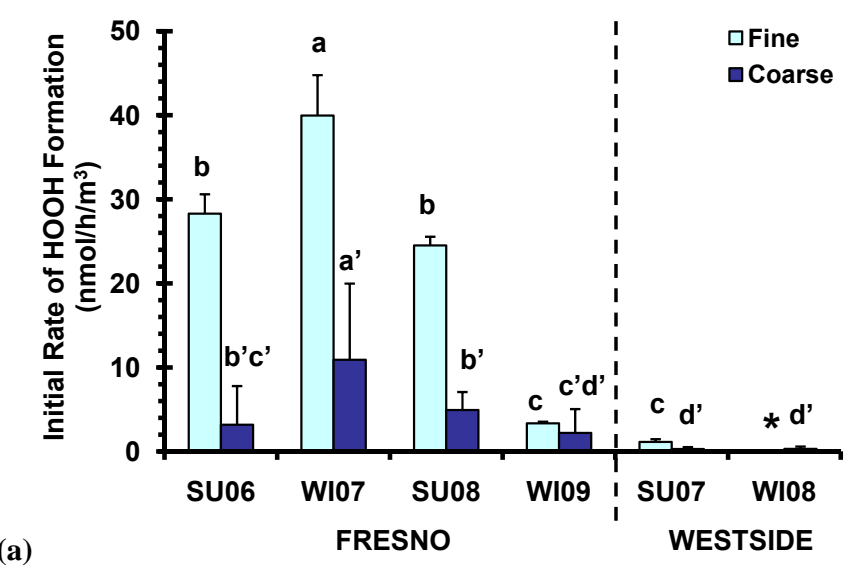

(a)

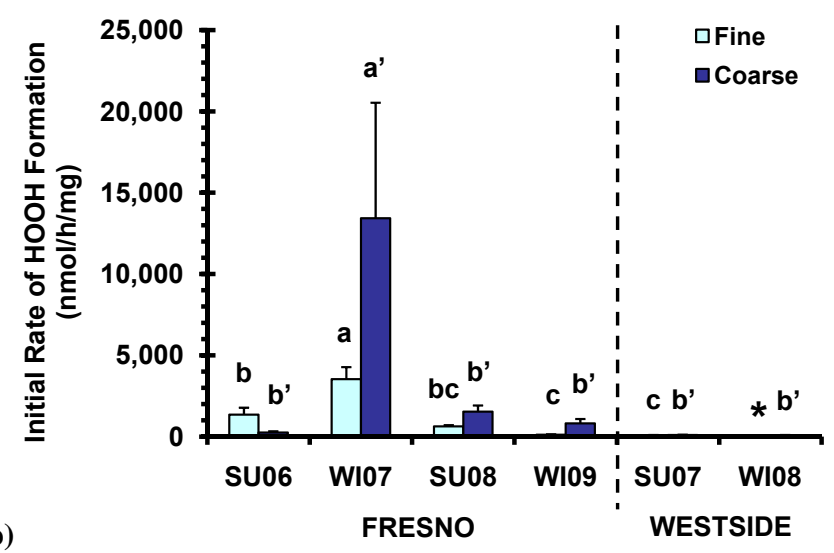

Fig. 2. Rates of $\mathrm{HOOH}$ generation in the presence of $50 \mu \mathrm{M}$ ascorbate. (a) shows air-volume-normalized initial rates of $\mathrm{HOOH}$ formation, while (b) shows PM-mass-normalized initial rates. Values are means $\pm \mathrm{SD}, n=3$. Letters above bars indicate statistically different rates: $a>b>c$ for fine PM, while $a^{\prime}>b^{\prime}>c^{\prime}>d^{\prime}$ for coarse PM. The asterisk for the WEWI08 sample indicates that $\mathrm{HOOH}$ formation was not statistically different from zero.

mass-normalized results (Fig. 2b). Although the coarse particles were more effective at making $\mathrm{HOOH}$ on a per-mass basis (Fig. 2b), there was much more fine PM mass during each sampling period (Table 1, Fig. S1) and thus the fine particles were overall more important for $\mathrm{HOOH}$ generation in the air masses (Fig. 2a). While these results are for the rate of $\mathrm{HOOH}$ formation, the same behavior was observed for the maximum $\mathrm{HOOH}$ measured (Fig. S3). Although our sample size is quite small, there is no evidence of a large seasonal difference in either the rate of $\mathrm{HOOH}$ generation (Fig. 2) or in the maximum levels formed (Fig. S3), although there are differences between the two winter campaigns.

\subsection{Generation of $\mathrm{HOOH}$ from PM extracts without added ascorbate}

The PM samples described above were all extracted in SLF containing $50 \mu \mathrm{M}$ ascorbate to mimic lung lining fluid concentrations of this antioxidant (van der Vliet et al., 1999; Cross et al., 1994). To examine the importance of ascorbate, we also measured $\mathrm{HOOH}$ formation in PM extracts without added Asc. Both the fine and coarse PM showed much lower initial rates of $\mathrm{HOOH}$ generation in SLF without Asc (Fig. 3) compared to SLF with added Asc (Fig. 2). The maximum amount of $\mathrm{HOOH}$ formed without Asc (Fig. S4) was also generally much lower compared to that with added Asc (Fig. S3). In the absence of Asc, the coarse PM generally had higher initial rates and maximum levels of $\mathrm{HOOH}$ formation than the corresponding fine PM, with the Fresno winter 2007 coarse PM being the most reactive sample (Fig. 3, Fig. S4). On average ( \pm 1 SD), the presence of ascorbate increased the maximum $\mathrm{HOOH}$ concentration for the Fresno fine and coarse PM by factors of, $110 \pm 90$ and $7 \pm 6$, respectively, independent of air-volume or PM-mass normalization.

The Fresno winter 2007 coarse PM was interesting because it was much more reactive than any other PM sample in generating $\mathrm{HOOH}$ without added ascorbate, especially on a mass-normalized basis (Fig. 3, Fig. S4). We compared $\mathrm{HOOH}$ formation from this sample under three different conditions: with added Asc, without added Asc, and with both Asc and DSF, a strong metal chelator that can eliminate $\mathrm{HOOH}$ generation by transition metals (Fig. S5). The results suggest that transition metals were the main contributor to the initial stage ( 0 to $1 \mathrm{~h}$ ) of $\mathrm{HOOH}$ formation, but that a metal-independent pathway was mostly responsible for the later stage ( 2 to $4 \mathrm{~h}$ ) of $\mathrm{HOOH}$ generation. While we do not know the identities of the compounds responsible for this pathway, PM contains a variety of organic compounds - such as quinones - that can generate ROS (Valavanidis et al., 2008). These results also suggest that there are unidentified reductants present in this sample that can redox-cycle metals (and organics) to make $\mathrm{HOOH}$ (Fig. S5). However, to put these results into perspective, for nearly all of our $\mathrm{PM}$ extracts, $\mathrm{HOOH}$ generation was dominated by metals as the redox-cycling agent (see Sect. 3.3) and ascorbate was the dominant reductant.

While there are no previous reports of $\mathrm{HOOH}$ production from ambient PM extracted in the presence of ascorbate, we can compare our results in the absence of ascorbate to work of Paulson and co-workers (Arellanes et al., 2006). This previous study measured $\mathrm{HOOH}$ in aqueous extracts of PM collected in the Los Angeles area and extracted for $2 \mathrm{~h}$ at room temperature in a $\mathrm{pH} 3.5$ aqueous solution containing $0.1 \mathrm{mM}$ EDTA. The average air-volume-normalized maximum level of $\mathrm{HOOH}$ generated by our Fresno fine $\mathrm{PM}$ in the absence of ascorbate $\left(0.44 \pm 0.24 \mathrm{nmol} \mathrm{m}^{-3}\right)$ is comparable to their results for fine PM collected near the 110 freeway $\left(0.35 \pm 0.26 \mathrm{nmol} \mathrm{m}^{-3}\right)$ and higher than 


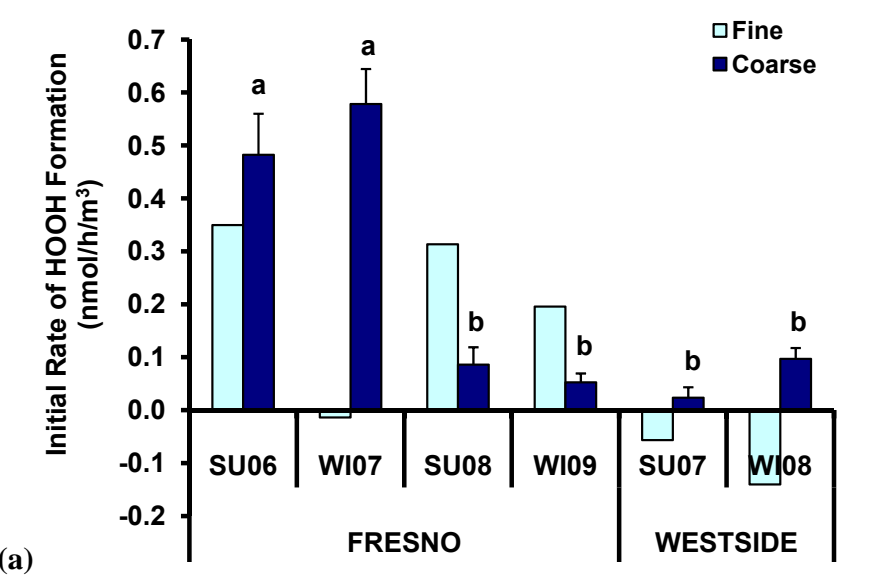

(a)

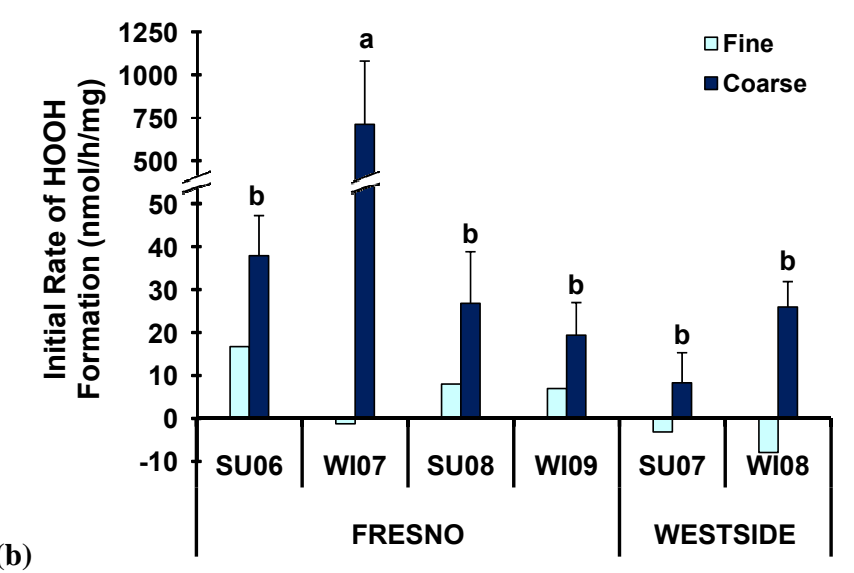

Fig. 3. Rates of $\mathrm{HOOH}$ generation in the absence of ascorbate. (a) shows air-volume-normalized initial rates of $\mathrm{HOOH}$ formation, while (b) shows PM-mass-normalized initial rates. Fine PM, $n=$ 1. Coarse $\mathrm{PM}$, values are means $\pm \mathrm{SD}, n=3$. Letters above bars indicate statistically different rates: $a>b$.

their UCLA fine PM results $\left(0.16 \pm 0.18 \mathrm{nmol} \mathrm{m}^{-3}\right)$ (Arellanes et al., 2006) (Fig. 4). Another recent study by the same group reported coarse PM-derived $\mathrm{HOOH}$ levels of $1.00 \pm 0.40$ and $0.50 \pm 0.22 \mathrm{nmol} \mathrm{m}^{-3}$ at two different sites in Riverside, California (Wang et al., 2010). These levels are lower than the average concentration of $\mathrm{HOOH}$ generated by our Fresno coarse PM $\left(2.8 \pm 3.2 \mathrm{nmol} \mathrm{m}^{-3}\right)$ but comparable to those produced by our Westside coarse PM $\left(0.39 \pm 0.36 \mathrm{nmol} \mathrm{m}^{-3}\right)$ in the absence of ascorbate. Other, earlier studies have reported aerosol-derived $\mathrm{HOOH}$ levels of $<0.0003$ to $0.29 \mathrm{nmol} \mathrm{m}^{-3}$ at Niwot Ridge, Colorado (Hewitt and Kok, 1991) and 0 to $0.38 \mathrm{nmol} \mathrm{m}^{-3}$ on the UCLA campus (Hasson and Paulson, 2003). On a PM-massnormalized basis, our results for $\mathrm{HOOH}$ generated in the absence of ascorbate are also similar to those from Arellanes et al. (Fig. S6). In contrast, in the presence of a relatively low level of ascorbate, our Fresno fine particles generated approximately 100 times more $\mathrm{HOOH}$ than they did in the

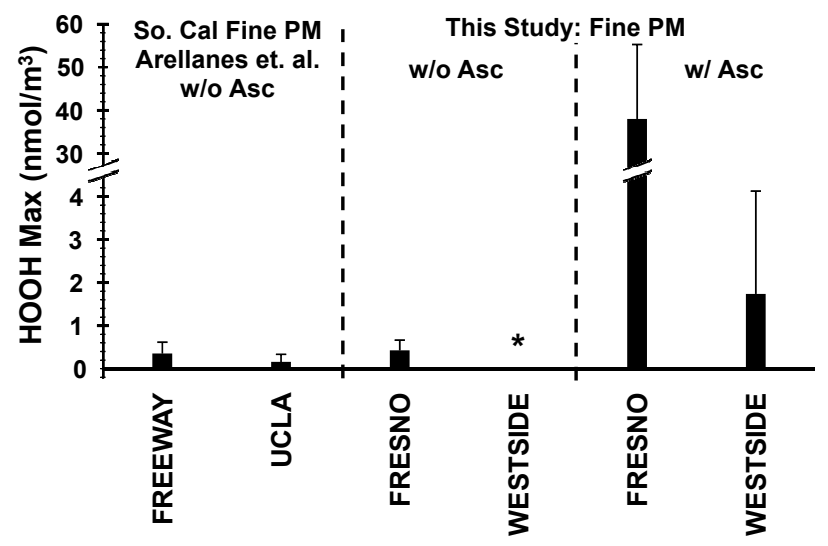

Fig. 4. Comparison of $\mathrm{HOOH}$ generation in SJV particles with results for fine PM from southern California (Arellanes et al., 2006). Air-volume-normalized $\mathrm{HOOH}$ maxima $\left(\mathrm{nmol} \mathrm{m}^{-3}\right)$ are shown. The Southern California fine PM samples were extracted for two $\mathrm{h}$ in an aqueous solution (0.10 mM EDTA, $\mathrm{pH} 3.5$, no ascorbate) (Arellanes et al., 2006). The asterisk indicates that $\mathrm{HOOH}$ formation in these samples was not statistically different from zero.

absence of ascorbate (Figs. 4 and S6). This has two implications: (1) endogenous ascorbate in the lung likely greatly amplifies $\mathrm{HOOH}$ production by deposited particles, and (2) in terms of the generation of $\mathrm{HOOH}$ (and, likely, other ROS), particle-borne reductants are probably relatively unimportant compared to ascorbate that is resident in the lung.

\subsection{SLF-soluble transition metals, especially $\mathrm{Cu}$, play a dominant role in $\mathrm{HOOH}$ generation from SJV PM}

As an initial exploration of the mechanisms for $\mathrm{HOOH}$ formation from our particles extracted in the presence of ascorbate, we performed replicate experiments where we added a strong metal chelator, DSF, to the extract solution in order to eliminate ROS generation by transition metals. As shown in Fig. 5, DSF reduced the initial rate of $\mathrm{HOOH}$ formation by 66 to $96 \%$ (on average, $(83 \pm 16) \%$ ) and 57 to $87 \%$ $((73 \pm 13) \%)$ for the fine and coarse PM, respectively, from both sites. Similarly, at both sites DSF decreased the maximum $\mathrm{HOOH}$ concentration by 65 to $89 \%((78 \pm 12) \%)$ and 40 to $76 \%((63 \pm 14) \%)$ for the fine and coarse PM, respectively (Fig. S7). These results indicate that these fractions of $\mathrm{HOOH}$ generation in the PM extracts were due to transition metals, i.e., that transition metals dominate $\mathrm{HOOH}$ production in the fine and coarse particles.

We also more specifically examined the role of SLFsoluble $\mathrm{Cu}$ in $\mathrm{HOOH}$ formation from the SJV PM; we focused on copper based on the effectiveness of the $\mathrm{Cu}$ positive control in generating $\mathrm{HOOH}$ and on past reports showing that $\mathrm{Cu}$ is an effective source of ROS (Vidrio et al., 2008; Rushton et al., 2010; DiStefano et al., 2009; Wang et al., 2010). As a first step, we examined the correlation 


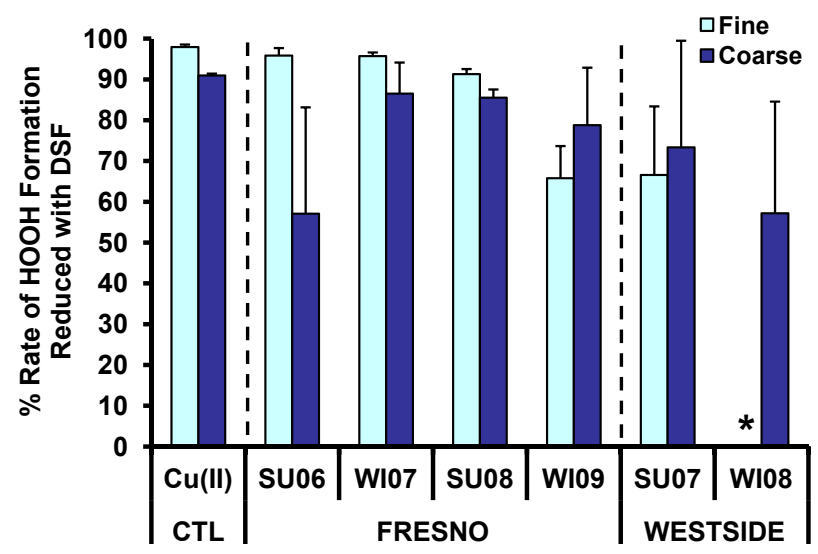

Fig. 5. Inhibitory effect of DSF on the initial rate of $\mathrm{HOOH}$ generation in SLF with ascorbate for the Cu control and the SJV PM. Values are means \pm SD. $n=3$ for extractions without added DSF, and $n=2$ for extractions with added DSF. The asterisk indicates that $\mathrm{HOOH}$ formation in this sample was not statistically different from zero.

of $\mathrm{HOOH}$ formation and SLF-soluble $\mathrm{Cu}$ in the SJV PM extracts: as shown in Fig. 6, the air-volume-normalized initial rate of $\mathrm{HOOH}$ formation by Fresno fine and coarse PM was correlated with SLF-soluble $\mathrm{Cu}\left(R^{2}=0.82\right)$. We also see a relationship between the air-volume-normalized maximum amount of $\mathrm{HOOH}$ formation and $\mathrm{Cu}$ in the Fresno samples, although it appears to be non-linear (Fig. S8). There was no correlation between $\mathrm{Cu}$ and the rate of $\mathrm{HOOH}$ formation in the Westside PM (Fig. 6).

In contrast to the strong correlation with $\mathrm{Cu}, \mathrm{HOOH}$ formation in the Fresno samples was not correlated with vanadium or manganese: correlation coefficients between the initial rate of $\mathrm{HOOH}$ formation and SLF-soluble V were 0.00 and 0.00 for the fine and coarse PM, respectively, while the corresponding values for SLF-soluble Mn were 0.00 and 0.35 . Because of iron contamination in some of our ICPMS aliquots we were unable to examine correlations between $\mathrm{Fe}$ and $\mathrm{HOOH}$ formation; however, we do not think Fe was a significant source of $\mathrm{HOOH}$ because control experiments with $50 \mu \mathrm{M} \mathrm{FeSO}_{4}$ in SLF containing $50 \mu \mathrm{M}$ ascorbate formed negligible amounts of $\mathrm{HOOH}$ after $4 \mathrm{~h}$ of shaking.

To quantitatively determine the contribution of copper to $\mathrm{HOOH}$ formation in the SJV particle extracts, we followed the procedure used previously by Vidrio et al. for quantifying the role of iron in ${ }^{\bullet} \mathrm{OH}$ formation (Vidrio et al., 2009). This determination involved four steps: (1) making "calibration curves" that quantify the initial rate and maximum level of $\mathrm{HOOH}$ formed from known concentrations of $\mathrm{Cu}$ in SLF containing $50 \mu \mathrm{M}$ ascorbate (Fig. S9); (2) using ICP-MS to measure the dissolved $\mathrm{Cu}$ concentration in each of the $\mathrm{PM}$ extracts (measured in aliquots removed after the 4-h time point in the $\mathrm{HOOH}$ measurements); (3) calculating the initial rate (and maximum level) of $\mathrm{HOOH}$ expected for each

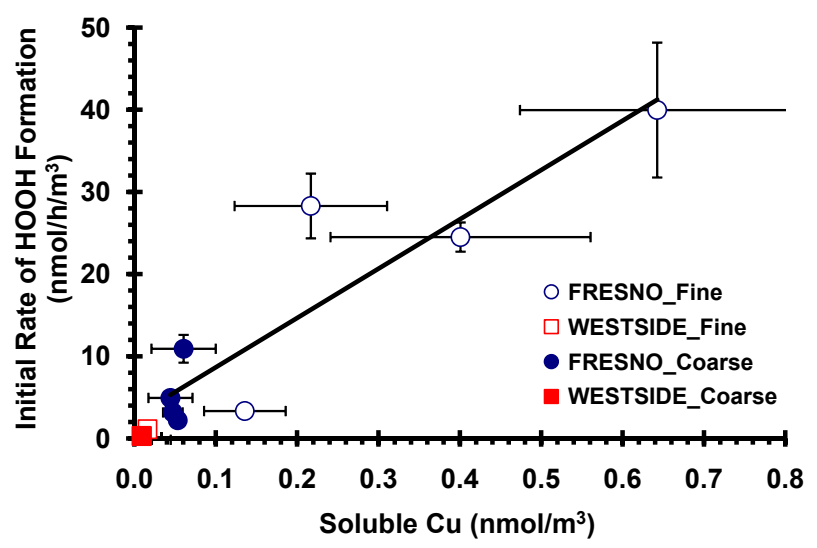

Fig. 6. Correlation between the air-volume-normalized initial rate of $\mathrm{HOOH}$ generation in SLF with Asc and the SLF-soluble Cu concentration in corresponding PM extracts. Values are means $\pm \mathrm{SD}$, $n=3$ for the $\mathrm{HOOH}$ rate, $n=4$ to 6 for the $\mathrm{Cu}$ concentration. The initial rates of $\mathrm{HOOH}$ formation by Fresno fine and coarse PM were strongly correlated with the SLF-soluble $\mathrm{Cu}$ concentrations in corresponding PM extracts: $y=60 x+2.66, R^{2}=0.82$. No correlation was observed between the SLF-soluble $\mathrm{Cu}$ concentrations and the initial rates of $\mathrm{HOOH}$ formation from the Westside $\mathrm{PM}\left(R^{2}=0.19\right)$.

PM extract based on the measured $\mathrm{Cu}$ and our calibration curves, and (4) examining the ratio of the calculated $\mathrm{HOOH}$ rate (or maximum) from $\mathrm{Cu}$ to the measured rate (or maximum) in a given sample. The ratio in this final step (i.e., calculated $\mathrm{HOOH}$ from $\mathrm{Cu} /$ measured $\mathrm{HOOH}$ ) is equivalent to the fraction of the observed $\mathrm{HOOH}$ that can be attributed to reactions of copper. As shown in Fig. 7, values of this ratio are generally around 1.0 for the Fresno PM samples, indicating that SLF-soluble $\mathrm{Cu}$ accounts for the majority of $\mathrm{HOOH}$ formation (Figs. 7 and S10); the average ratios for the Fresno fine and coarse PM were $2.13 \pm 1.48$ and $1.42 \pm 0.86$ for the rate of $\mathrm{HOOH}$ formation, and $1.60 \pm 0.77$ and $1.01 \pm 0.31$ for maximum $\mathrm{HOOH}$, respectively. It is unclear why the ratios are above 2 for the winter 2009 Fresno samples, but this might be due to inhibition of copper reactivity due to organic ligands in the particles. For the Westside PM samples the picture is less clear, in part because the rates of $\mathrm{HOOH}$ formation were much smaller and, therefore, less certain (Figs. 7 and S10). However, even in these samples the ratios of (calculated $\mathrm{HOOH}$ from $\mathrm{Cu} /$ measured $\mathrm{HOOH}$ ) are near 1 , although they are highly uncertain. Copper can also explain why Fresno coarse PM is generally more efficient at generating $\mathrm{HOOH}$ on a PM-mass-normalized basis than is fine PM (Fig. 2b, Fig S3b): the Fresno coarse particles generally have higher amounts of PM-mass normalized soluble copper (i.e., ng-Cu $\mu g^{-1}-\mathrm{PM}$ ) than the Fresno fine PM (Table 1). This key role of $\mathrm{Cu}$ in $\mathrm{HOOH}$ generation from the Fresno PM is an interesting contrast to our previous finding that dissolved Fe dominates ${ }^{\bullet} \mathrm{OH}$ generation from $\mathrm{PM}_{2.5}$ collected in Davis, CA (Vidrio et al., 2009). This difference might indicate that 


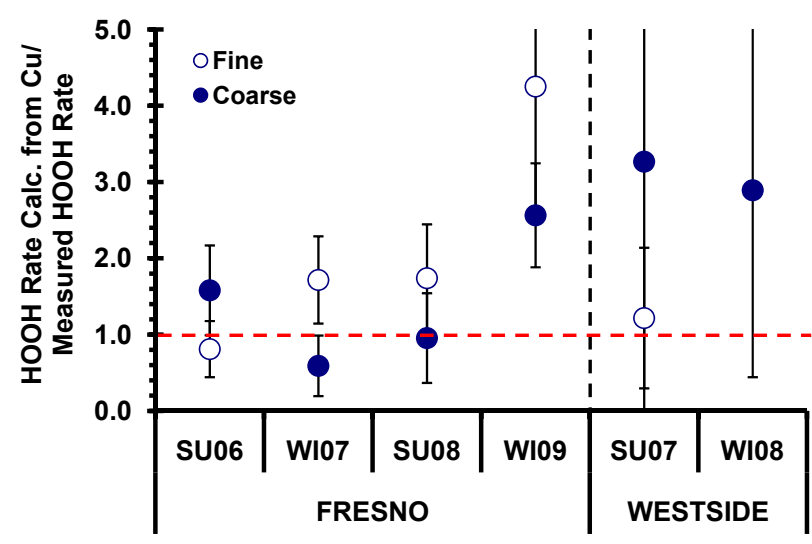

Fig. 7. Contribution of SLF-soluble $\mathrm{Cu}$ to the initial rate of $\mathrm{HOOH}$ generation in SLF with Asc. Each point represents the ratio of the initial rate of $\mathrm{HOOH}$ formation expected from the measured concentration of $\mathrm{Cu}$ in the SLF extract of the PM to the initial rate of $\mathrm{HOOH}$ formation measured for the sample. Values are means \pm SD. $n=4$ to 6 for the calculated $\mathrm{HOOH}$ rate from $\mathrm{Cu}, n=3$ for the measured $\mathrm{HOOH}$ rate. The Westside winter 2008 fine PM data point is not shown because $\mathrm{HOOH}$ generation in this sample was not significantly different from zero.

different metals are responsible for different ROS, but it also might be due to the fact that the SLF used in the ${ }^{\bullet} \mathrm{OH}$ study contained both ascorbate and citrate, since citrate inhibits the ability of $\mathrm{Cu}$ to form ${ }^{\bullet} \mathrm{OH}$ (Charrier and Anastasio, 2011).

Our findings that transition metals play a dominant role in $\mathrm{HOOH}$ formation from the SJV PM is consistent with numerous previous studies that have linked particulate transition metals to PM-induced cytotoxicity and health effects (Valavanidis et al., 2008; Lippmann and Chen, 2009). Our finding that $\mathrm{Cu}$ specifically is responsible for the bulk of $\mathrm{HOOH}$ formation is also consistent with in vitro and in vivo studies that have shown that $\mathrm{Cu}$ can be responsible for the toxicity of PM, via ROS generation, oxidative stress, DNA oxidative damage, tight junction protein damage, pulmonary injury and inflammation (Shi et al., 2003; Gasser et al., 2009; Wallenborn et al., 2009; Rushton et al., 2010). While we do not know the source of $\mathrm{Cu}$ in our particle samples, one possibility is brake wear, which emits particles that have relatively high copper concentrations (Gasser et al., 2009; Bukowiecki et al., 2009). This source is consistent with the fact that our urban (Fresno) site is close to a major highway and multiple surface streets, while the rural (Westside) site has very little nearby traffic.

\section{Implications and uncertainties}

We have found that aqueous extracts of San Joaquin Valley particles produce $\mathrm{HOOH}$, and that endogenous levels of ascorbate greatly amplify this production. But are these amounts of $\mathrm{HOOH}$ significant for human health? To ad- dress this question, we will compare the threshold levels of $\mathrm{HOOH}$ that cause toxicity (based on previous reports) with the amounts of $\mathrm{HOOH}$ expected from deposition of particles in the lungs (based on our results). There is good consistency for $\mathrm{HOOH}$ thresholds among in vitro studies: the lowest levels of $\mathrm{HOOH}$ tested - approximately 30 to $50 \mu \mathrm{M}$ - induce cell injury in a wide variety of respiratory tract cells, including rabbit and rat type II pneumocytes, rat alveolar macrophages, and human lung epithelial cells (Holm et al., 1991; Crim and Longmore, 1995; Sporn et al., 1992; Geiser et al., 2004; Oosting et al., 1990; Hyslop et al., 1988; LaCagnin et al., 1990). Although we cannot specify an exact threshold because lower levels of $\mathrm{HOOH}$ were not tested, these studies suggest that approximately $30 \mu \mathrm{M}$ of $\mathrm{HOOH}-$ and possibly less - causes toxicity.

Using our results we can calculate the concentrations of PM-mediated $\mathrm{HOOH}$ expected in the lung lining fluid based on our maximum measured $\mathrm{HOOH}$ levels and assuming 24-h of PM inhalation:

$\mathrm{HOOH}$ concentration in lung lining fluid $(\mu \mathrm{MHOOH})$

$=\frac{\text { Maximum HOOH generated per air volume }\left(\mathrm{nmol} \mathrm{HOOH} \mathrm{m}^{-3}\right)}{1000 \mathrm{nmol} \mu \mathrm{mol}^{-1}}$

Volume of air inhaled $\left(\mathrm{m}^{3}\right) \times$ Fraction of inhaled PM that are deposited Volume of lung lining fluid (L)

Using the average of the maximum $\mathrm{HOOH}$ production amounts measured after $4 \mathrm{~h}$ of PM extraction $\left(38 \mathrm{nmol} \mathrm{m}^{-3}\right.$ for Fresno and $1.7 \mathrm{nmol} \mathrm{m}^{-3}$ for Westside; Fig. 4), an inhaled air volume of $20 \mathrm{~m}^{3}$ per day, an average adult lung lining fluid volume of $25 \mathrm{~mL}$ (Walters, 2002), and assuming 30\% of inhaled $\mathrm{PM}_{2.5}$ deposits in lungs (Sarangapani and Wexler, 2000), we estimate $\mathrm{HOOH}$ lung lining fluid concentrations of 9 and $0.4 \mu \mathrm{M} \mathrm{HOOH}$ in Fresno and Westside, respectively, from 24-h of $\mathrm{PM}_{2.5}$ inhalation. Similarly, by using the average maximum levels of $\mathrm{HOOH}$ of $7.4 \mathrm{nmol} \mathrm{m}^{-3}$ (Fresno) and $0.8 \mathrm{nmol} \mathrm{m}^{-3}$ (Westside) and assuming $70 \%$ of inhaled $\mathrm{PM}_{\mathrm{cf}}$ deposits in lungs (Sarangapani and Wexler, 2000), the average $\mathrm{HOOH}$ lung lining fluid concentrations from inhalation of coarse PM are 4 and $0.5 \mu \mathrm{M} \mathrm{HOOH}$ for Fresno and Westside, respectively. Taken together, the estimated average lung lining fluid concentrations of $\mathrm{PM}$-mediated $\mathrm{HOOH}$ are 13 and $0.9 \mu \mathrm{M}$ HOOH from Fresno and Westside particles, respectively, with 69 and $48 \%$ of $\mathrm{HOOH}$ formation at these two sites from fine PM. For individual samples, the ranges of estimated particle-mediated $\mathrm{HOOH}$ in lung lining fluid range from 6 to 18 and 0.5 to $1 \mu \mathrm{M}$ for Fresno and Westside particles, respectively.

Comparing these estimated lung $\mathrm{HOOH}$ concentrations with previous in vitro findings suggests that levels of PMmediated $\mathrm{HOOH}$ from Fresno particles are typically below the acute toxicity threshold of $\sim 30$ to $50 \mu \mathrm{M}$, but that high PM events might have enough soluble copper that the resulting $\mathrm{HOOH}$ could be toxic on short time scales. (In contrast, $\mathrm{PM}$-mediated $\mathrm{HOOH}$ at Westside is likely always insignificant.) Furthermore, peak $\mathrm{PM}_{2.5}$ events in Fresno 
have much higher PM mass concentrations than our samples, which likely translates to higher copper amounts and more $\mathrm{HOOH}$; for example, the maximum 24-h average concentration of $\mathrm{PM}_{2.5}$ was approximately $100 \mu_{\mathrm{g} \mathrm{m}}^{-3}$ in both 2006 and 2007 (California Air Resources Board, 2010), which is about 3 times higher than our average Fresno $\mathrm{PM}_{2.5}$ concentration $\left(33 \mu \mathrm{g} \mathrm{m}^{-3}\right.$; Table 1$)$. In addition, the high levels of $\mathrm{PM}_{2.5}$ found in Fresno are typical of many other polluted regions, both in the US and globally, suggesting that the $\mathrm{HOOH}$-mediated toxicity of particles might be important in many polluted regions with particulate metals. Finally, while the above comparison considers only acute exposures, it is possible that the $\mathrm{PM}$-mediated generation of $\mathrm{HOOH}$ might be important at lower $\mathrm{HOOH}$ concentrations in chronic exposures.

While our results suggest that the chemical generation of $\mathrm{HOOH}$ from inhaled ambient particles can sometimes lead to toxic effects, there are a number of uncertainties. Perhaps most significantly, our work was performed in a cell-free system and so does not include biological responses that could either enhance toxicity (e.g., macrophage generation of ROS in response to PM) or reduce it (e.g., catalase-mediated decomposition of $\mathrm{HOOH}$ ). Furthermore, PM-derived concentrations of $\mathrm{HOOH}$ in lung lining fluid are likely lower than those estimated from our solutions because of the diffusion of $\mathrm{HOOH}$ across cell membranes (which might lead to toxic effects) and its enzymatic and chemical decomposition. Despite this, our measurements give an indication of the flux of $\mathrm{HOOH}$ that can be generated in vivo from PM deposition; given past in vitro studies on $\mathrm{HOOH}$ toxicity, our results suggest that $\mathrm{HOOH}$ fluxes associated with very high PM loadings (with sufficient transition metal content) could be associated with toxic effects. Another uncertainty in our results is the effect of the composition of the SLF extraction solution on $\mathrm{HOOH}$ generation: while ascorbate was the only antioxidant that we included in our extraction solution, recent work has shown that other lung fluid antioxidants (e.g. glutathione) and components (e.g. citrate) can significantly decrease the ability of $\mathrm{Cu}$ to generate ${ }^{\circ} \mathrm{OH}$ (Vidrio et al., 2008; Charrier and Anastasio, 2011), although it is not clear if these species also affect $\mathrm{HOOH}$ generation. Finally, while we have used $50 \mu \mathrm{M}$ of ascorbate in our extractions, this is at the lower end of levels measured in human lung lining fluid (Cross et al., 1994; van der Vliet et al., 1999) and we expect that $\mathrm{HOOH}$ production would be higher at greater ascorbate concentrations.

\section{Conclusions}

We have quantified the formation of $\mathrm{HOOH}$ in cell-free aqueous extracts of particulate matter from an urban and rural site in the San Joaquin Valley (SJV) of California. Our results show that: (1) in general, the urban (Fresno) samples generate more $\mathrm{HOOH}$ than the rural (Westside) samples; (2) there is no clear seasonal (summer vs. winter) difference in $\mathrm{HOOH}$ generation; (3) normalized by air volume, the fine PM generally makes more $\mathrm{HOOH}$ than the corresponding coarse PM. However, normalized by PM mass, the coarse PM typically generates more $\mathrm{HOOH}$ than the fine PM; (4) the presence of a physiologically relevant level of ascorbate in the extraction solution greatly enhances the formation of $\mathrm{HOOH}$, and (5) transition metals, especially SLF-soluble $\mathrm{Cu}$, play a dominant role in $\mathrm{HOOH}$ generation from the SJV PM.

To our knowledge this is the first study that has quantified the generation of $\mathrm{HOOH}$ from PM in a surrogate lung fluid solution containing added reductant (ascorbate). While it is difficult to extrapolate from our cell-free results to potential biological effects, a comparison of our results with past in vitro acute studies suggests that $\mathrm{HOOH}$ generation from inhaled particles might cause toxic effects at high levels of ambient particles, especially in samples with high copper concentrations.

\section{Supplementary material related to this article is available online at: http://www.atmos-chem-phys.net/11/753/2011/ acp-11-753-2011-supplement.pdf.}

Acknowledgements. We thank Yongjing Zhao, Walter Ham, Mike Kleeman, Chris Ruehl, and Norman Kado for PM sample collection, Ann Dillner and Brian Devine for designing and fabricating the filter punch, Yuee Pan for assisting with sampling, and David Barnes for providing the microbalance. This research was funded by the US Environmental Protection Agency through grant number RD-83241401-0 to the San Joaquin Valley Aerosol Health Effects Research Center at the University of California, Davis. The contents are solely the responsibility of the authors and do not necessarily represent the official views of the EPA. Additional funding was provided by the California Agricultural Experiment Station (Project CA-D*-LAW-6403-RR).

Edited by: M. Ammann

\section{References}

Alaghmand, M. and Blough, N. V.: Source-dependent variation in hydroxyl radical production by airborne particulate matter, Environ. Sci. Technol., 41, 2364-2370, 2007.

Arellanes, C., Paulson, S. E., Fine, P. M., and Sioutas, C.: Exceeding of Henry's law by hydrogen peroxide associated with urban aerosols, Environ. Sci. Technol., 40, 4859-4866, 2006.

Baulig, A., Poirault, J. J., Ausset, P., Schins, R., Shi, T. M., Baralle, D., Dorlhene, P., Meyer, M., Lefevre, R., Baeza-Squiban, A., and Marano, F.: Physicochemical characteristics and biological activities of seasonal atmospheric particulate matter sampling in two locations of Paris, Environ. Sci. Technol., 38, 5985-5992, 2004.

Bukowiecki, N., Lienemann, P., Hill, M., Figi, R., Richard, A., Furger, M., Rickers, K., Falkenberg, G., Zhao, Y. J., Cliff, S. S., Prevot, A. S. H., Baltensperger, U., Buchmann, B., and Gehrig, 
R.: Real-world emission factors for antimony and other brake wear related trace elements: size-segregated values for light and heavy duty vehicles, Environ. Sci. Technol., 43, 8072-8078, 2009.

California Air Resources Board: The California almanac of emissions and air quality - 2009 edition, available at: http://www.arb. ca.gov/aqd/almanac/almanac09/almanac09.htm, 2010.

Charrier, J. G. and Anastasio, C.: Impacts of antioxidants on hydroxyl radical production from individual and mixed transition metals in a surrogate lung fluid, Atmos. Environ., in press, 2011.

Cho, A. K., Sioutas, C., Miguel, A. H., Kumagai, Y., Schmitz, D. A., Singh, M., Eiguren-Fernandez, A., and Froines, J. R.: Redox activity of airborne particulate matter at different sites in the Los Angeles Basin, Environ. Res., 99, 40-47, 2005.

Crim, C. and Longmore, W. J.: Sublethal hydrogen peroxide inhibits alveolar type II cell surfactant phospholipid biosynthetic enzymes, Am. J. Physiol., 268, L129-135, 1995.

Cross, C. E., Vandervliet, A., Oneill, C. A., Louie, S., and Halliwell, B.: Oxidants, antioxidants, and respiratory-tract lining fluids, Environ. Health Perspect., 102, 185-191, 1994.

Deguillaume, L., Leriche, M., Desboeufs, K., Mailhot, G., George, C., and Chaumerliac, N.: Transition metals in atmospheric liquid phases: sources, reactivity, and sensitive parameters, Chem. Rev., 105, 3388-3431, 2005.

DiStefano, E., Eiguren-Fernandez, A., Delfino, R. J., Sioutas, C., Froines, J. R., and Cho, A. K.: Determination of metal-based hydroxyl radical generating capacity of ambient and diesel exhaust particles, Inhal. Toxicol., 21, 731-738, 2009.

Dockery, D. W., Pope, C. A., 3rd, Xu, X., Spengler, J. D., Ware, J. H., Fay, M. E., Ferris Jr., B. G., and Speizer, F. E.: An association between air pollution and mortality in six U.S. cities, N. Engl. J. Med., 329, 1753-1759, 1993.

Donaldson, K., Brown, D. M., Mitchell, C., Dineva, M., Beswick, P. H., Gilmour, P., and MacNee, W.: Free radical activity of $\mathrm{PM}_{10}$ : iron-mediated generation of hydroxyl radicals, Environ. Health Perspect., 105, 1285-1289, 1997.

Donaldson, K., Stone, V., Borm, P. J., Jimenez, L. A., Gilmour, P. S., Schins, R. P., Knaapen, A. M., Rahman, I., Faux, S. P., Brown, D. M., and MacNee, W.: Oxidative stress and calcium signaling in the adverse effects of environmental particles $\left(\mathrm{PM}_{10}\right)$, Free Radic. Biol. Med., 34, 1369-1382, 2003.

Feierman, D. E., Winston, G. W., and Cederbaum, A. I.: Ethanol oxidation by hydroxyl radicals - role of iron chelates, superoxide, and hydrogen-peroxide, Alcohol. Clin. Exp. Res., 9, 95-102, 1985.

Forman, H. J., Maiorino, M., and Ursini, F.: Signaling functions of reactive oxygen species, Biochemistry, 49, 835-842, 2010.

Gasser, M., Riediker, M., Mueller, L., Perrenoud, A., Blank, F., Gehr, P., and Rothen-Rutishauser, B.: Toxic effects of brake wear particles on epithelial lung cells in vitro, Part. Fibre Toxicol., 6(30), doi:10.1186/1743-8977-6-30, 2009.

Geiser, T., Ishigaki, M., van Leer, C., Matthay, M. A., and Broaddus, V. C.: $\mathrm{H}_{2} \mathrm{O}_{2}$ inhibits alveolar epithelial wound repair in vitro by induction of apoptosis, Am. J. Physiol. Lung Cell. Mol. Physiol., 287, L448-453, 2004.

Ghio, A. J., Stonehuerner, J., Dailey, L. A., and Carter, J. D.: Metals associated with both the water-soluble and insoluble fractions of an ambient air pollution particle catalyze an oxidative stress, Inhal. Toxicol., 11, 37-49, 1999.
Gonzalez-Flecha, B.: Oxidant mechanisms in response to ambient air particles, Mol. Aspects Med., 25, 169-182, 2004.

Hasson, A. S. and Paulson, S. E.: An investigation of the relationship between gas-phase and aerosol-borne hydroperoxides in urban air, J. Aerosol Sci., 34, 459-468, 2003.

Hetland, R. B., Refsnes, M., Myran, T., Johansen, B. V., Uthus, N., and Schwarze, P. E.: Mineral and/or metal content as critical determinants of particle-induced release of IL- 6 and IL- 8 from A549 cells, J. Toxicol. Environ. Health A, 60, 47-65, 2000.

Hewitt, C. N. and Kok, G. L.: Formation and occurrence of organic hydroperoxides in the troposphere - laboratory and field observations, J. Atmos. Chem., 12, 181-194, 1991.

Holm, B. A., Hudak, B. B., Keicher, L., Cavanaugh, C., Baker, R. R., Hu, P., and Matalon, S.: Mechanisms of $\mathrm{H}_{2} \mathrm{O}_{2}$-mediated injury to type II cell surfactant metabolism and protection with PEG-catalase, Am. J. Physiol., 261, C751-757, 1991.

Hung, H. F. and Wang, C. S.: Experimental determination of reactive oxygen species in Taipei aerosols, J. Aerosol Sci., 32, 12011211, 2001.

Hyslop, P. A., Hinshaw, D. B., Halsey, W. A., Jr., Schraufstatter, I. U., Sauerheber, R. D., Spragg, R. G., Jackson, J. H., and Cochrane, C. G.: Mechanisms of oxidant-mediated cell injury. The glycolytic and mitochondrial pathways of ADP phosphorylation are major intracellular targets inactivated by hydrogen peroxide, J. Biol. Chem., 263, 1665-1675, 1988.

Hyslop, P. A., Hinshaw, D. B., Scraufstatter, I. U., Cochrane, C. G., Kunz, S., and Vosbeck, K.: Hydrogen peroxide as a potent bacteriostatic antibiotic: implications for host defense, Free Radic. Biol. Med., 19, 31-37, 1995.

Jimenez, L. A., Thompson, J., Brown, D. A., Rahman, I., Antonicelli, F., Duffin, R., Drost, E. M., Hay, R. T., Donaldson, K., and MacNee, W.: Activation of NF-kappaB by PM $_{10}$ occurs via an iron-mediated mechanism in the absence of IkappaB degradation, Toxicol. Appl. Pharmacol., 166, 101-110, 2000.

Jung, H., Guo, B., Anastasio, C., and Kennedy, I. M.: Quantitative measurements of the generation of hydroxyl radicals by soot particles in a surrogate lung fluid, Atmos. Environ., 40, 1043-1052, 2006.

Kennedy, T., Ghio, A. J., Reed, W., Samet, J., Zagorski, J., Quay, J., Carter, J., Dailey, L., Hoidal, J. R., and Devlin, R. B.: Copperdependent inflammation and nuclear factor-kappaB activation by particulate air pollution, Am. J. Respir. Cell Mol. Biol., 19, 366378, 1998.

Knaapen, A. M., Shi, T., Borm, P. J., and Schins, R. P.: Soluble metals as well as the insoluble particle fraction are involved in cellular DNA damage induced by particulate matter, Mol. Cell. Biochem., 234-235, 317-326, 2002.

Kok, G. L., McLaren, S. E., and Staffelbach, T. A.: HPLC determination of atmospheric organic hydroperoxides, J. Atmos. Oceanic Technol., 12, 282-289, 1995.

Kunzli, N., Mudway, I. S., Gotschi, T., Shi, T., Kelly, F. J., Cook, S., Burney, P., Forsberg, B., Gauderman, J. W., Hazenkamp, M. E., Heinrich, J., Jarvis, D., Norback, D., Payo-Losa, F., Poli, A., Sunyer, J., and Borm, P. J.: Comparison of oxidative properties, light absorbance, total and elemental mass concentration of ambient PM2.5 collected at 20 European sites, Environ. Health Perspect., 114, 684-690, 2006.

LaCagnin, L. B., Bowman, L., Ma, J. Y., and Miles, P. R.: Metabolic changes in alveolar type II cells after exposure to hydrogen per- 
oxide, Am. J. Physiol., 259, L57-65, 1990.

Laskin, D. L., Morio, L., Hooper, K., Li, T. H., Buckley, B., and Turpin, B.: Peroxides and macrophages in the toxicity of fine particulate matter in rats, Res. Rep. Health Eff. Inst., 1-51; discussion 53-63, 2003.

Li, N., Xia, T., and Nel, A. E.: The role of oxidative stress in ambient particulate matter-induced lung diseases and its implications in the toxicity of engineered nanoparticles, Free Radic. Biol. Med., 44, 1689-1699, 2008.

Lippmann, M. and Chen, L. C.: Health effects of concentrated ambient air particulate matter (CAPs) and its components, Crit. Rev. Toxicol., 39, 865-913, 2009.

McGregor, G. P. and Biesalski, H. K.: Rationale and impact of vitamin $C$ in clinical nutrition, Curr. Opin. Clin. Nutr. Metab. Care, 9, 697-703, 2006.

Morio, L. A., Hooper, K. A., Brittingham, J., Li, T. H., Gordon, R. E., Turpin, B. J., and Laskin, D. L.: Tissue injury following inhalation of fine particulate matter and hydrogen peroxide is associated with altered production of inflammatory mediators and antioxidants by alveolar macrophages, Toxicol. Appl. Pharmacol., 177, 188-199, 2001.

Oosting, R. S., van Bree, L., van Iwaarden, J. F., van Golde, L. M., and Verhoef, J.: Impairment of phagocytic functions of alveolar macrophages by hydrogen peroxide, Am. J. Physiol., 259, L8794, 1990.

Padayatty, S. J., Katz, A., Wang, Y. H., Eck, P., Kwon, O., Lee, J. H., Chen, S. L., Corpe, C., Dutta, A., Dutta, S. K., and Levine, M.: Vitamin $\mathrm{C}$ as an antioxidant: evaluation of its role in disease prevention, J. Am. Coll. Nutr., 22, 18-35, 2003.

Pekkanen, J., Peters, A., Hoek, G., Tiittanen, P., Brunekreef, B., de Hartog, J., Heinrich, J., Ibald-Mulli, A., Kreyling, W. G., Lanki, T., Timonen, K. L., and Vanninen, E.: Particulate air pollution and risk of ST-segment depression during repeated submaximal exercise tests among subjects with coronary heart disease: the exposure and risk assessment for fine and ultrafine particles in ambient air (ULTRA) study, Circulation, 106, 933-938, 2002.

Pope III, C. A. and Dockery, D. W.: Health effects of fine particulate air pollution: lines that connect, J. Air Waste Manage. Assoc., 56, 709-742, 2006.

Pope III, C. A., Thun, M. J., Namboodiri, M. M., Dockery, D. W., Evans, J. S., Speizer, F. E., and Heath Jr., C. W.: Particulate air pollution as a predictor of mortality in a prospective study of U.S. adults, Am. J. Respir. Crit. Care Med., 151, 669-674, 1995.

Pope III, C. A., Burnett, R. T., Thurston, G. D., Thun, M. J., Calle, E. E., Krewski, D., and Godleski, J. J.: Cardiovascular mortality and long-term exposure to particulate air pollution: epidemiological evidence of general pathophysiological pathways of disease, Circulation, 109, 71-77, 2004.

Prahalad, A. K., Soukup, J. M., Inmon, J., Willis, R., Ghio, A. J., Becker, S., and Gallagher, J. E.: Ambient air particles: effects on cellular oxidant radical generation in relation to particulate elemental chemistry, Toxicol. Appl. Pharmacol., 158, 81-91, 1999.

Prahalad, A. K., Inmon, J., Dailey, L. A., Madden, M. C., Ghio, A. J., and Gallagher, J. E.: Air pollution particles mediated oxidative DNA base damage in a cell free system and in human airway epithelial cells in relation to particulate metal content and bioreactivity, Chem. Res. Toxicol., 14, 879-887, 2001.

Rushton, E. K., Jiang, J., Leonard, S. S., Eberly, S., Castranova, V., Biswas, P., Elder, A., Han, X. L., Gelein, R., Finkelstein, J., and Oberdorster, G.: Concept of assessing nanoparticle hazards considering nanoparticle dosemetric and chemical/biological response metrics, J. Toxicol. Environ. Health A, 73, 445-461, 2010.

Sarangapani, R. and Wexler, A. S.: The role of dispersion in particle deposition in human airways, Toxicol. Sci., 54, 229-236, 2000.

Satoh, K. and Sakagami, H.: Effect of metal ions on radical intensity and cytotoxic activity of ascorbate, Anticancer Res., 17 1125-1129, 1997.

Schaumann, F., Borm, P. J., Herbrich, A., Knoch, J., Pitz, M., Schins, R. P., Luettig, B., Hohlfeld, J. M., Heinrich, J., and Krug, N.: Metal-rich ambient particles (particulate matter 2.5) cause airway inflammation in healthy subjects, Am. J. Respir. Crit. Care Med., 170, 898-903, 2004.

Shi, T., Knaapen, A. M., Begerow, J., Birmili, W., Borm, P. J., and Schins, R. P.: Temporal variation of hydroxyl radical generation and 8-hydroxy-2'-deoxyguanosine formation by coarse and fine particulate matter, Occup. Environ. Med., 60, 315-321, 2003.

Shy, C. M.: Epidemiologic evidence and the United States air quality standards, Am. J. Epidemiol., 110, 661-671, 1979.

Sporn, P. H., Marshall, T. M., and Peters-Golden, M.: Hydrogen peroxide increases the availability of arachidonic acid for oxidative metabolism by inhibiting acylation into phospholipids in the alveolar macrophage, Am. J. Respir. Cell Mol. Biol., 7, 307-316, 1992.

Stadtman, E. R.: Ascorbic acid and oxidative inactivation of proteins, Am. J. Clin. Nutr., 54, 1125S-1128S, 1991.

Valavanidis, A., Fiotakis, K., and Vlachogianni, T.: Airborne particulate matter and human health: toxicological assessment and importance of size and composition of particles for oxidative damage and carcinogenic mechanisms, J. Environ. Sci. Health C Environ. Carcinog. Ecotoxicol. Rev., 26, 339-362, 2008.

van der Vliet, A., O’Neill, C. A., Cross, C. E., Koostra, J. M., Volz, W. G., Halliwell, B., and Louie, S.: Determination of lowmolecular-mass antioxidant concentrations in human respiratory tract lining fluids, Am. J. Physiol. Lung Cell. Mol. Physiol., 276, L289-296, 1999.

Venkatachari, P., Hopke, P. K., Grover, B. D., and Eatough, D. J.: Measurement of particle-bound reactive oxygen species in $\mathrm{Ru}-$ bidoux aerosols, J. Atmos. Chem., 50, 49-58, 2005.

Venkatachari, P., Hopke, P. K., Brune, W. H., Ren, X. R., Lesher, R., Mao, J. Q., and Mitchel, M.: Characterization of wintertime reactive oxygen species concentrations in Flushing, New York, Aerosol Sci. Technol., 41, 97-111, 2007.

Vidrio, E., Jung, H., and Anastasio, C.: Generation of hydroxyl radicals from dissolved transition metals in surrogate lung fluid solutions, Atmos. Environ., 42, 4369-4379, 2008.

Vidrio, E., Phuah, C. H., Dillner, A. M., and Anastasiot, C.: Generation of hydroxyl radicals from ambient fine particles in a surrogate lung fluid solution, Environ. Sci. Technol., 43, 922-927, 2009.

Wallenborn, J. G., Schladweiler, M. J., Richards, J. H., and Kodavanti, U. P.: Differential pulmonary and cardiac effects of pulmonary exposure to a panel of particulate matter-associated metals, Toxicol. Appl. Pharmacol., 241, 71-80, 2009.

Walters, D. V.: Lung lining liquid - the hidden depths - the 5th NILS W Svenningsen Memorial Lecture, Biol. Neonate, 81, 2-5, 2002.

Wang, Y., Arellanes, C., Curtis, D. B., and Paulson, S. E.: Probing the source of hydrogen peroxide associated with coarse mode 
aerosol particles in Southern California, Environ. Sci. Technol., 44, 4070-4075, 2010.

Ware, J. H., Thibodeau, L. A., Speizer, F. E., Colome, S., and Ferris Jr., B. G.: Assessment of the health effects of atmospheric sulfur oxides and particulate matter: evidence from observational studies, Environ. Health Perspect., 41, 255-276, 1981.

Wexler, A. S. and Sarangapani, R.: Particles do not increase vapor deposition in human airways, J. Aerosol Sci., 29, 197-204, 1998.

Wilson, D. W., Aung, H. H., Lame, M. W., Plummer, L., Pinkerton, K. E., Ham, W., Kleeman, M., Norris, J. W., and Tablin, F.: Exposure of mice to concentrated ambient particulate matter results in platelet and systemic cytokine activation, Inhal. Toxicol., 22, 267-276, 2010.
Yokoyama, T., Date, C., Kokubo, Y., Yoshiike, N., Matsumura, Y., and Tanaka, H.: Serum vitamin C concentration was inversely associated with subsequent 20 -year incidence of stroke in a Japanese rural community. The Shibata study, Stroke, 31, 2287-2294, 2000.

Zepp, R. G., Faust, B. C., and Hoigne, J.: Hydroxyl radical formation in aqueous reactions (pH 3-8) of iron(II) with hydrogenperoxide - the photo-fenton reaction, Environ. Sci. Technol., 26, 313-319, 1992. 